\title{
Classification of Product Knowledge - An Approach to Optimal Feedback Strategies for Design
}

\author{
P. Dietz, A. Ort, S. Penschke \\ Institut für Maschinenwesen, TU Clausthal \\ Robert-Koch-Straße 32, \\ D-38678 Clausthal-Zellerfeld, \\ Tel.: +495323 72-2270, Fax: +495323 72-3501, \\ Email:dietz@imw.tu-clausthal.de
}

\begin{abstract}
Product data modelling and management has become an increasingly feature for enterprises in order to strengthen their competitive position. Modelling can be regarded as a requirement analysis, whilst management is a means to apply powerful application to product data. This data describes the status of a product during the whole product life cycle as well as the transformation of one state to another. Operations performed in one phase of the product will definitely have impact on later phases and the product itself. It is of interest to analyse this impact and to extract methods to assist the designer of a product in order to improve the quality of a product.

Based on an internal analysis of European research projects, this paper shows how product data management is used during the product life cycle of a product and how it can improve a products quality. The goal is to derive support strategies for the designer based upon the data structure and knowledge representation used within these projects. It describes an approach to measure product data structures and design knowledge representations. Different levels of complexity concerning the managed product knowledge in design support systems have been identified as well as different design support strategies.
\end{abstract}

\section{Keywords}

product data modelling, product knowledge management, reuse of information, knowledge classification techniques for optimal feedback strategies, design support (systems) 


\section{INTRODUCTION}

The work with design support systems is basically initiated by the need to assure competitiveness in the future for manufacturing enterprises. Many competitive factors have to be taken into consideration in connection with market behaviour, product types, production volumes, specialisation etc. In general product costs, product quality and the delivery at the right time are the key factors. The pressure to reduce the time to market for new products and therefore to reduce the development time, requires an adequate use of know how possessed by a company. The decisions made by the designer are responsible for 70 to $80 \%$ of product costs, since materials, manufacturing methods or usage properties are more or less determined in this phase. Therefore the product quality mainly depends on the quality of decision making at the design stage.

In manufacturing enterprises the products knowledge is distributed across the whole company. This know how represents an essential resource for successful competition in the market and should therefore be preserved and used as efficiently as possible. A way of reaching this goal exists in the use of knowledge based systems which contain accumulated product knowledge on different aspects during the product life cycle, e.g. design, manufacturing, usage, recycling (Figure 1, following Krause 1994).

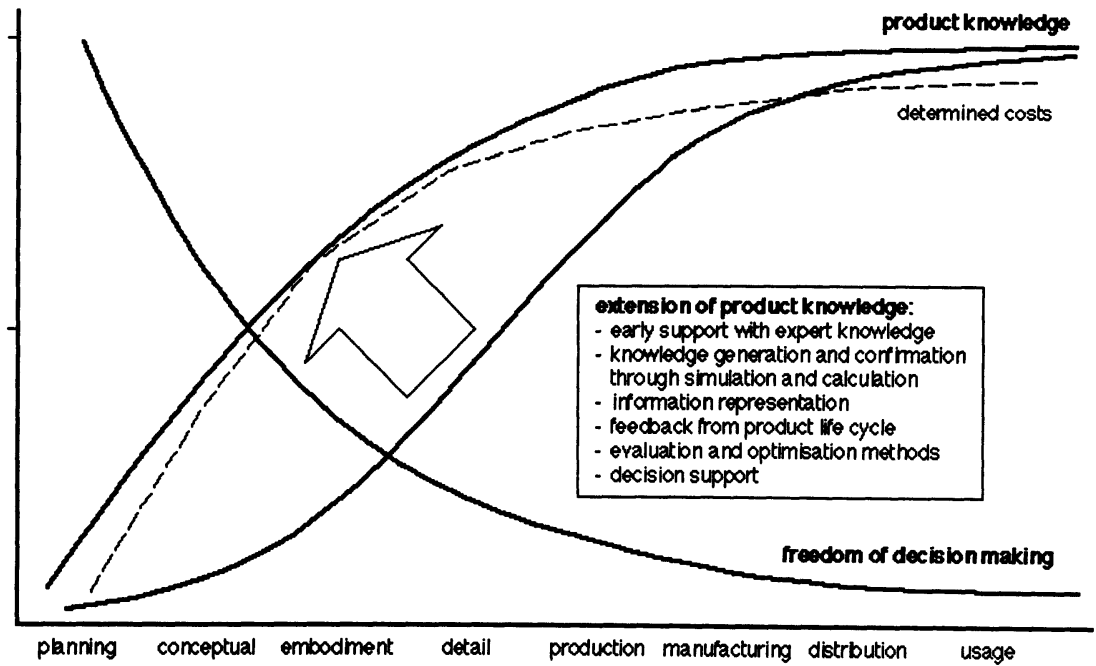

Figure 1 Extension of product knowledge by the use of information technology.

This paper is based on (Dietz, 1997), which identifies major strategies on how product knowledge can be used during design. The resources used for this analysis were research projects with the participation of the Institute for Mechanical Engineering in the field of design, manufacturing and quality assurance. The following 
two tables summarize the project objectives and outputs. The numbers are used for later reference in the paper.

Table 1 Overview of analysed national projects for this paper

\begin{tabular}{|c|c|c|c|}
\hline Name & Aim & Approach & Output \\
\hline $\begin{array}{l}6 \text { QCIM-PM } \\
\text { (Quality } \\
\text { through CIM - } \\
\text { Product } \\
\text { Model) }\end{array}$ & $\begin{array}{l}\text { to develop a tool to } \\
\text { recognise, analyse } \\
\text { and visualise } \\
\text { requirements dyna- } \\
\text { mically in the } \\
\text { design process }\end{array}$ & $\begin{array}{l}\text { define requirements } \\
\text { by their properties } \\
\text { requirements stored } \\
\text { as a textual descrip- } \\
\text { tion or as mathe- } \\
\text { matical expression }\end{array}$ & $\begin{array}{l}\text { prototype to test } \\
\text { the theoretical } \\
\text { approach of multi- } \\
\text { dimensional re- } \\
\text { quirement struc- } \\
\text { tures and relations }\end{array}$ \\
\hline $\begin{array}{l}\text { (Compare e.g. } \\
\text { DIN, 1997.) }\end{array}$ & $\begin{array}{l}\text { support the designer } \\
\text { in the early phases } \\
\text { of the design } \\
\text { reuse of already } \\
\text { existing knowledge } \\
\text { from all phases of } \\
\text { the product life } \\
\text { cycle }\end{array}$ & $\begin{array}{l}\text { interrelationships } \\
\text { provide knowledge } \\
\text { about the inter- } \\
\text { actions of require- } \\
\text { ments }\end{array}$ & $\begin{array}{l}\text { requirement inter- } \\
\text { relationships are a } \\
\text { major problem, } \\
\text { since the designer } \\
\text { is seldom aware } \\
\text { of implicit } \\
\text { conflicts. }\end{array}$ \\
\hline $\begin{array}{l}\text { } 7 \text { SFB } 362 \\
\text { (Sheet metal } \\
\text { design for } \\
\text { manu- } \\
\text { facturing) } \\
\text { (Compare e.g. } \\
\text { Dietz, 1997.) }\end{array}$ & $\begin{array}{l}\text { to develop basic } \\
\text { design methodolo- } \\
\text { gies for sheet metal } \\
\text { products and meet } \\
\text { their requirements } \\
\text { of function and } \\
\text { manufacturing } \\
\text { adaptation of } \\
\text { requirements and } \\
\text { functions to con- } \\
\text { sider geometrical } \\
\text { restrictions depen- } \\
\text { ding on material } \\
\text { properties and pro- } \\
\text { cessing parameters } \\
\text { in early stages of } \\
\text { the design process }\end{array}$ & $\begin{array}{l}\text { use of Information } \\
\text { model and a proto- } \\
\text { type for sheet metal } \\
\text { design support. } \\
\text { specification of } \\
\text { requirements for a } \\
\text { new sheet metal } \\
\text { part during product } \\
\text { planning } \\
\text { to define a sheet } \\
\text { metal part that } \\
\text { meets the require- } \\
\text { ments and that is } \\
\text { optimal in the view } \\
\text { of manufacturing. }\end{array}$ & $\begin{array}{l}\text { prototype to test } \\
\text { the developed } \\
\text { design for manu- } \\
\text { facturing } \\
\text { approach } \\
\text { further research } \\
\text { will focus espe- } \\
\text { cially on the pro- } \\
\text { vision of a higher } \\
\text { semantic level to } \\
\text { support metho- } \\
\text { dical operating. }\end{array}$ \\
\hline
\end{tabular}


Table 2 Overview of analyzed international projects for this paper

\begin{tabular}{|c|c|c|c|}
\hline Name & Aim & Approach & Output \\
\hline $\begin{array}{l}\text { ( PICASSO } \\
\text { (Practical and } \\
\text { Intelligent } \\
\text { CAD for } \\
\text { Assembly } \\
\text { Objects) } \\
\text { BriteEuram } \\
\text { BE II } 5693 \\
\text { (Compare e.g. } \\
\text { PICASSO, } \\
\text { 1996.) }\end{array}$ & $\begin{array}{l}\text { development of a } \\
\text { design } \\
\text { methodology for } \\
\text { assemblies } \\
\text { support of a CAD } \\
\text { tool for assemblies } \\
\text { concentrating on } \\
\text { tolerance infor- } \\
\text { mation (according } \\
\text { to ISO 286), ma- } \\
\text { chine components } \\
\text { and process tools. }\end{array}$ & $\begin{array}{l}\text { an assembly defini- } \\
\text { tion phase } \\
\text { operation with a set } \\
\text { of rules specified as } \\
\text { part of the assembly } \\
\text { template definition } \\
\text { system handles } \\
\text { knowledge about } \\
\text { how mould com- } \\
\text { ponents are assem- } \\
\text { bled } \\
\text { rules and formulae } \\
\text { used as represen- } \\
\text { tation }\end{array}$ & $\begin{array}{l}\text { first application of } \\
\text { the system in the } \\
\text { design of plastic } \\
\text { spray moulding } \\
\text { and press tools } \\
\text { improvement of } \\
\text { the prototype by } \\
\text { one of the partners } \\
\text { and is being used } \\
\text { for embodiment } \\
\text { and detailed } \\
\text { design. }\end{array}$ \\
\hline $\begin{array}{l}\text { (2) EQUIP } \\
\text { (Work Metho- } \\
\text { dology for } \\
\text { Development } \\
\text { of Quite } \\
\text { Products } \\
\text { BE II } 5983 \\
\text { (Compare e.g. } \\
\text { EQUIP, 1997.) }\end{array}$ & $\begin{array}{l}\text { provision of a con- } \\
\text { sulting system to } \\
\text { obtain low noise } \\
\text { products from well } \\
\text { conducted design } \\
\text { to obtain know- } \\
\text { ledge about the } \\
\text { information flow } \\
\text { concerning noise } \\
\text { control in the } \\
\text { design process } \\
\text { to indentify what } \\
\text { kind of information } \\
\text { is needed, ex- } \\
\text { changed and } \\
\text { created }\end{array}$ & $\begin{array}{l}\text { set up of a metho- } \\
\text { dology for the } \\
\text { design of low noise } \\
\text { products } \\
\text { denotation in form } \\
\text { of a SADT model } \\
\text { an additional infor- } \\
\text { mation model capa- } \\
\text { ble of containing all } \\
\text { noise relevant data } \\
\text { for products }\end{array}$ & $\begin{array}{l}\text { a sofware proto- } \\
\text { type providing a } \\
\text { knowledge base } \\
\text { of product } \\
\text { relevant data } \\
\text { a design support } \\
\text { tool helping to } \\
\text { analyse an assem- } \\
\text { bled product in } \\
\text { accordance with } \\
\text { to its noise } \\
\text { characteristics } \\
\text { enhancement of } \\
\text { the software to an } \\
\text { industrial product } \\
\text { and is maintained } \\
\text { by one of the } \\
\text { partners. }\end{array}$ \\
\hline
\end{tabular}


Table 2 Overview of analyzed international projects for this paper (continue)

\begin{tabular}{|c|c|c|c|}
\hline Name & Aim & Approach & Output \\
\hline $\begin{array}{l}3 \text { PLUS } \\
\text { (Parts } \\
\text { Libraries } \\
\text { Usage and } \\
\text { Supply) }\end{array}$ & $\begin{array}{l}\text { utilise a (stan- } \\
\text { dardized) meta de- } \\
\text { scription for part } \\
\text { libraries for the } \\
\text { comparability and } \\
\text { exchange of parts }\end{array}$ & $\begin{array}{l}\text { use of object orien- } \\
\text { ted technology for } \\
\text { modeling of the } \\
\text { meta schema } \\
\text { data structures can } \\
\text { cone with the highly }\end{array}$ & $\begin{array}{l}\text { provision of pre- } \\
\text { industrial proto- } \\
\text { types of parts } \\
\text { libraries of which } \\
\text { one is being co- } \\
\text { mercially sold. }\end{array}$ \\
\hline $\begin{array}{l}\text { ESPRIT } 8984 \\
\text { (Compare e.g. } \\
\text { Sardet, 1997].) }\end{array}$ & $\begin{array}{l}\text { improvement in } \\
\text { search and } \\
\text { selection of parts } \\
\text { by structured } \\
\text { description of parts }\end{array}$ & $\begin{array}{l}\text { complex organized } \\
\text { data }\end{array}$ & \\
\hline $\begin{array}{l}(4 \text { AMANIS } \\
\text { (Advanced } \\
\text { Manufacturing } \\
\text { Information } \\
\text { System for the }\end{array}$ & $\begin{array}{l}\text { collection and pre- } \\
\text { paration of current } \\
\text { company-specific } \\
\text { manufacturing } \\
\text { information }\end{array}$ & $\begin{array}{l}\text { handling of manu- } \\
\text { facturing times, } \\
\text { costs and proble- } \\
\text { matic events to be } \\
\text { expected during } \\
\text { manufacturing }\end{array}$ & $\begin{array}{l}\text { developed system } \\
\text { for use in the } \\
\text { embodiment and } \\
\text { detail design } \\
\text { phase }\end{array}$ \\
\hline $\begin{array}{l}\text { Designer) } \\
\text { BE II } 5139 \\
\text { (Compare e.g. } \\
\text { AMANIS, } \\
\text { 1995.) }\end{array}$ & $\begin{array}{l}\text { to provide manu- } \\
\text { facturing informa- } \\
\text { tion to the designer } \\
\text { in a convenient } \\
\text { way }\end{array}$ & $\begin{array}{l}\text { programming of a } \\
\text { set of tools based on } \\
\text { autonomous know- } \\
\text { ledge aquisition } \\
\text { algorithms and neu- } \\
\text { ral network tech- } \\
\text { niques }\end{array}$ & $\begin{array}{l}\text { system is being } \\
\text { sold commercially } \\
\text { by one of the } \\
\text { partners. }\end{array}$ \\
\hline
\end{tabular}

5 ProManual develop a metho- identify knowledge two prototypes of (Intelligent lligent product tures Product manuals

Manuals)

INCO-COP

$96 / 0231$

define data sources

of in design phases

intelligent product manuals (machine tool, agricultural machinery)

(Compare Ort, 1997.)

to be used for

manual data

use multimedia

technology 
The developed strategies were analysed by taking their field of research and objectives into account. This survey has extracted knowledge management approaches and feedback strategies, which will be discussed in this paper. Chapter 2 briefly introduces the existing approaches dealing with engineering knowledge. Chapter 3 will look more specifically at the results of the cited survey and chapter 4 will contain a summation of the conclusions.

\section{ANALYSIS OF HANDLED ENGINEERING KNOWLEDGE}

There is a multitude of exertions dealing with the problem of systematisation of knowledge in general and especially of engineering knowledge. For instance, each research on design object representation can be regarded more or less as an effort to systematise design knowledge. Therefore the following small survey could surely not be complete. In general all of these efforts represent different views on the problem, after taking several aspects into account.

\section{Human structures}

One important point of view may be human memory structures and psychological interrelationships in problem solving. The cognitive structure of a human is distinguished in two fields, the epistemic and the heuristic structure (Dörner 1979). The first contains a system of categories which structures the knowledge about facts and applicable operators. It determines the capability of solving tasks reproductively. The second structure represents a library of procedures (methods) for problem solving, i.e. a system of meta or inside operators to build operators. It will be used if no solving method is immediately retrievable. Furthermore the memory structure may be interpreted as a kind of semantic network whose nodes represent contents and whose connections are relations between the contents. A human has the opportunity to detect, use and build specific relations such as concreteabstract-relations, whole-part-relations or space-time-relations. These relations play a significant role in how knowledge can be represented in supporting systems and shall be carefully distinguished. The concrete-abstract-relation for instance is the major relation for building electronic part catalogues or part libraries (ISO, 1996) and (DIN, 1998). After selecting parts and inserting them into a current design, this part will be represented in the whole-part-relation, which is the basis of each product model. However, modelling the design process itself requires the space-time-relation. A human has no problems in managing this mixture of relations. It may, however, cause problems for support systems in the process of representing or reusing knowledge.

(Yoshikawa 1993) emphasises the necessity for a knowledge standard (in the context of constructing very large knowledge bases). There is a given classification of knowledge in two dimensions:

- recognised - unrecognised knowledge and 
- codified - tacit knowledge.

Tacit knowledge could be explicitly or implicitly recognised by human beings and used for reasoning but is very difficult to describe (e.g. the so-called commonsense). Codified knowledge is always recognised and described with symbols, figures etc. (e.g. textbook knowledge, information stored in a database). Expertise and skill are mostly composed of unrecognised and tacit knowledge. Unrecognised and codified knowledge is meaningless. The primary goal of systematisation of knowledge is to convert recognised and tacit knowledge into recognised and codified knowledge. This conversion will make it computable and improve its reusage and sharing.

In order to systematise engineering knowledge, the consideration of human memory and cognitive structures appears to be too abstract. Nevertheless, it is useful to support information modelling and structuring of knowledge bases analogously to the human memory because it eases its access.

\section{Artificial Intelligence}

Another point of view is from the field of artificial intelligence (Görz, 1993). Resulting from this are a number of distinctions concerning knowledge. The first distinction is to differentiate data (e.g. a, b, c, 100, 2), information (e.g. a =2, b = 100 ) and knowledge (e.g. $\mathrm{c}=\mathrm{a} * \mathrm{~b}$ ). The second distinction follows the general subdivision of artificial intelligence systems into three broad categories (Nilsson, 1982). The knowledge about a problem domain which is represented in a global database is called declarative knowledge. It would include specific facts like data and relations between the data. The knowledge about a problem that is represented in a set of rules is called procedural knowledge. It would include general information that allows a manipulation of the declarative knowledge. The knowledge of a problem that is represented by a control strategy is called control knowledge. This includes a variety of processes, strategies and structures used to coordinate the entire problem solving process. In (Pham, 1991) the kernel of intelligent knowledge based systems consists of a knowledge base containing knowledge about a problem domain (e.g. facts, information, rules of judgement; also called domain) and an inference mechanism for manipulating the stored knowledge to produce solutions to problems (also known as inference engine, control structure or reasoning mechanism; also called task). Ideally, domain and task are independent of each other. A third distinction is possible which concerns the most popular ways of knowledge representation: One can differentiate into rule-based (knowledge in terms of facts and rules for manipulating facts), framebased (a frame, concept, schema or unit as a recordlike structure, a form for encoding on a stereotyped situation; associated with a frame is a set of attributes, the descriptions or values of which are contained in slots) and semantic net-based (semantic nets are similar to frames; it is a network or graph of nodes linked together by arcs, arcs represent relations) representations. Case and rule bases are 
sometimes called shallow knowledge in contrast to schemes using frames, semantic nets, graphs or modells which are called deep knowledge.

\section{Domains}

In addition to the above there are several efforts to systematise knowledge from the engineering domain. Following an analysis of main sub-activities in design (Lenau, 1989] introduces a division of engineering knowledge by:

- documentation of design considerations (documentation of thoughts/ideas of the designer in order to explore the feasibility of different solutions and to be able to discuss them with other people, e.g. sketches and drawings),

- modelling/drawing (usually based on CAD systems, containing at least geometry and dimensions, currently becoming a complete product description),

- textual information (e.g. descriptions, specifications, instructions),

- rules/calculations (e.g. re-design of complex mechanisms like bearings or gears),

- material information (to explore and select materials e.g. on the basis of part geometry, properties, characteristics and manufacturing possibilities) and

- process information (to take the manufacturing implications into consideration, interrelationships e.g. between product characteristics and manufacturing possibilities or between part geometry and manufacturing process).

The information handling behaviour of the designer could be another criteria for knowledge systematisation. A framework for describing informational behaviour is presented in (Baya, 1994) to observe empiric experiments. Serveral definitions are made in order to classify so called information fragments:

- informational activity (e.g. generate, access, analyse),

- descriptor (e.g. requirement, operation, location, comparison, alternative, relation),

- subject class (e.g. requirement, concept, assembly, component, connection, feature, attribute),

- subject,

- medium (e.g. text, graphic, list, simulation),

- level of abstraction (e.g. associative, qualitative, quantitativ) and

- level of detail (e.g. conceptual, configurational, detail).

Two types of design knowledge are also identified:

- design process knowledge (which describes how) and

- design object knowledge (which is largely fact knowledge to describe what).

A design process begins with ambiguous or rough descriptions of the design object and which will gradually be detailed and completed. 


\section{APPLYING KNOWLEDGE SYSTEMATISATION}

For the analysis feedback strategies in the research projects, a two step approach was chosen. First, two scales to measure the projects in terms of complexity and durability of the handled data were defined. The second step was to position the properties of products into a time scale in order to uncover the relevance of some properties for the product life cycle.

\subsection{Measuring the knowledge data}

This step is driven by the aspect of knowledge systematisation in design science (Hubka, 1996), (Pahl, 1993). The goal is to derive a kind of 'sophistication level' of possible design support. As a measure, the sophistication level of knowledge representation is chosen. The presumption is that a high grade of knowledge representation is a basis for a high grade design support: the level certainly matches with different representation forms of knowledge. In relation to the complexity of engineering knowledge it may be devided into:

- structured data description (e.g. verbal or graphic information, data bases)

- rules (e.g. if -- then)

- functions (e.g. formulae, constraints)

- analysis methods (e.g. calculation, simulation, neural nets, reasoning mechanisms)

- single processes (e.g. design subactivities) and

- connected processes (e.g. methodical approach, computable design process model).

Simple knowledge is represented as plain structured data whereas complexity increases with relationships, such as rules or formulae up to interactively working (system) processes triggered by design activities. Main points are structured data descriptions, rules and functions. All of the systems have the ability to handle such information. Analysis methods are represented to a lesser degree due to the existence of powerful applications for engineering problems (e.g. FEM systems, calculation programs for various mechanical components, tools for kinematic simulation) which are not part of the systems itself. There appears to be, however, a lack of applications concerning process oriented information.

The following figure shows the position of each project in this scale. Since various representations apply for one project, some of them wil occur more than once. It is clear, that most of the projects handle more less complex data structures. 


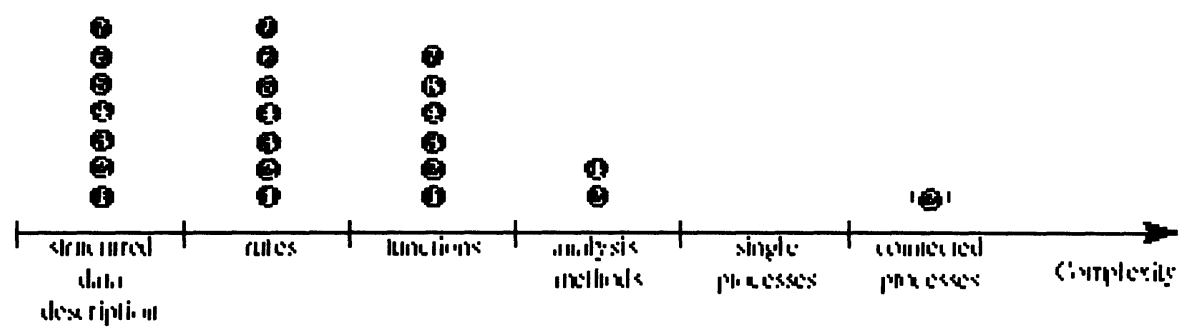

Figure 2 Complexity of handled knowledge

The second scale reflects the complexity of data in respect to time. It shows how fast the content of data may change, whereas the scale above measures only the structure of data. The temporal behaviour of knowledge is also an important aspect on knowledge characterisation. The durability of knowledge, in terms of time, means that the amount of changes that take place depends on the data the system is fed with. Durable means that once the data is inserted, no more chnages will occur (i.e. lifespan of several years, e.g. bearing calculation method, general guidelines for embodiment design such as designing to allow for expansion, standards and regulations) and can be used unreflected (premising that it is correct) in this state. Unsettled means that the data undergoes permanent change (i.e. lifespan of several days, e.g. capacity utilisation, occupation of machines, stock information) and thits use depends mainly on the time. We used a scale from one to five to roughly characterise the data used in the systems of each project. The spearhead unambiguously lies on durable information. One has to ask how useful is a design support with unsettled information. Nowadays, due to concurrent engineering approaches and a production in a turbulent environment, unsettled information has become of increasing interest as a support of development processes.

The following figure depicts the expected results: most of the projects handle rather static data, i.e. data on which the system can rely on once it is inserted into the database. It is clear that this kind of database is easier to control and to maintain whereas highly unsettled data requires a permanent update and an event control mechanism. The latter handles possible system changes due to data changes.

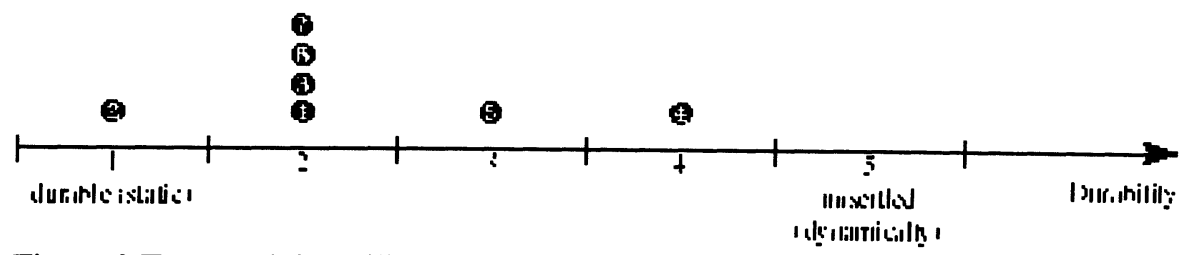

Figure 3 Temporal durability of handled knowledge

The last two figures show that most of the projects handle static data and stick to a more simple representation of knowledge. This is naturally due to the enormous 
degree of complexity one has to handle with more sophisticated systems. However, this analysis shows the direction to which further research should head, i.e. systems which can handle more time critical data (as a major requirement form the industry) and with it naturally more complex information structures and support activities. It is important to note, that changes in data structures have not been considered yet. This may be another point to emphasise in furture projects.

\subsection{Relation between product data and time}

As seen above, time plays an important role in the knowledge representation. It is therefore of interest to analyse the relation between data classification and the time scale of the design process. The goal is to identify which kindof data is time critical or rather which kind of data is important for the complete design process. For this reason, product properties have been defined. The method of characterising products using properties is state of the art and intesively used in the parts library standard. For representing the properties over an axis of time, a matrix representation is used which stem from the field of feature modelling. (Weber, 1996). There a feature is defined in the scope of a specific view onto the product description with respect to:

- phases of the product life cycle (product life cycle is a model to distinguish between significant phases of product creation, usage and replacement) and

- classes of product properties (a class of properties is a combination of properties, which can be logical structured).

A view describes the way to look at the product and its properties during the product life cycle. In compliance with the various approaches the matrix representation considering product properties and life cycle is quite suitable to represent engineering knowledge handled in the systems as described in chapter 2 . In this way the content of information concerning the product and the usage of system functionality with regard to each stage of design/developement is described. The following figure depicts this classification. The numbers refere to the projects as introduced in chapter 2.

Making use of a matrix representation, the scope of the project applications can be neatly represented. The table indicates clearly the main field of application. It seems that the major need for support lies in the embodiment and the detailed design phase. The heavy loaded vertical axis of the product property class requirements shows the importance of an integrated requirement management. 
Table 3 Description of handled engineering knowledge with respect to information content and usage during life cycle

\begin{tabular}{|c|c|c|c|c|c|c|c|c|}
\hline & $\begin{array}{l}\text { mar- } \\
\text { keting }\end{array}$ & $\begin{array}{l}\text { pro- } \\
\text { duct } \\
\text { plan- } \\
\text { ning } \\
\end{array}$ & $\begin{array}{l}\text { con- } \\
\text { ceptual } \\
\text { design }\end{array}$ & $\begin{array}{l}\text { embo- } \\
\text { diment } \\
\text { design }\end{array}$ & $\begin{array}{l}\text { detail } \\
\text { design }\end{array}$ & $\begin{array}{l}\text { manu- } \\
\text { factu- } \\
\text { plan- } \\
\text { ning } \\
\end{array}$ & $\begin{array}{l}\text { manu } \\
\text { factu- }\end{array}$ & $\ldots$ \\
\hline $\begin{array}{l}\text { requirements } \\
\text { functions }\end{array}$ & & $\begin{array}{c}256 \\
7 \\
5\end{array}$ & $\begin{array}{c}025 \\
60 \\
25\end{array}$ & $\begin{array}{c}125 \\
60 \\
20\end{array}$ & $\begin{array}{c}10 \\
60 \\
5\end{array}$ & 6 & 6 & 5 \\
\hline $\begin{array}{l}\text { solution } \\
\text { principles }\end{array}$ & & & 2 & 2 & & & & \\
\hline $\begin{array}{l}\text { geometry } \\
\text { tolerances }\end{array}$ & & 0 & (5) & $\begin{array}{c}135 \\
7 \\
103\end{array}$ & $\begin{array}{l}030 \\
03\end{array}$ & & & 5 \\
\hline materials & & 0 & & 30 & 30 & & & \\
\hline $\begin{array}{l}\text { manufacturing } \\
\text { methods and } \\
\text { parameters }\end{array}$ & & 0 & & 40 & 40 & 4 & 4 & \\
\hline $\begin{array}{l}\text { strength and } \\
\text { durability }\end{array}$ & & & 5 & 35 & 3 & & & \\
\hline costs & & & & 030 & 034 & 4 & 4 & \\
\hline time & & & & 4 & 4 & 4 & 4 & \\
\hline usage properties & & 25 & 25 & 236 & 23 & 2 & & 5 \\
\hline $\begin{array}{l}\text { environmental } \\
\text { properties }\end{array}$ & & & & 3 & 3 & & & 5 \\
\hline
\end{tabular}

\subsection{Knowledge feedback strategies to design}

Considering the analysed projects and theresults above, it can be observed that design support relies mainly on feedback information, i.e. information from a later life cycle phase of a product back to the early stages of a new one. Operations performed in one phase of the product will surely have impact on later phases and the product itself. The different systems showed various aspects of the feedback which will be elaborated in this chapter. 
In the beginning, when a product is developed from scratch, ideally no experience at all exists for this product. The designer will enter each phase of the development trying to make optimal decisions for the future. Only when a phase is finished or the product is already in use and when he observes possible drawbacks in the handling of his product, he may be able to connect those drawbacks (the symptom) to decisions in some phases (the cause) he had made. This process is purely manual based on designers own experiences since the system itself does not know or recognise anything of these interrelationships, i.e. none feedback.
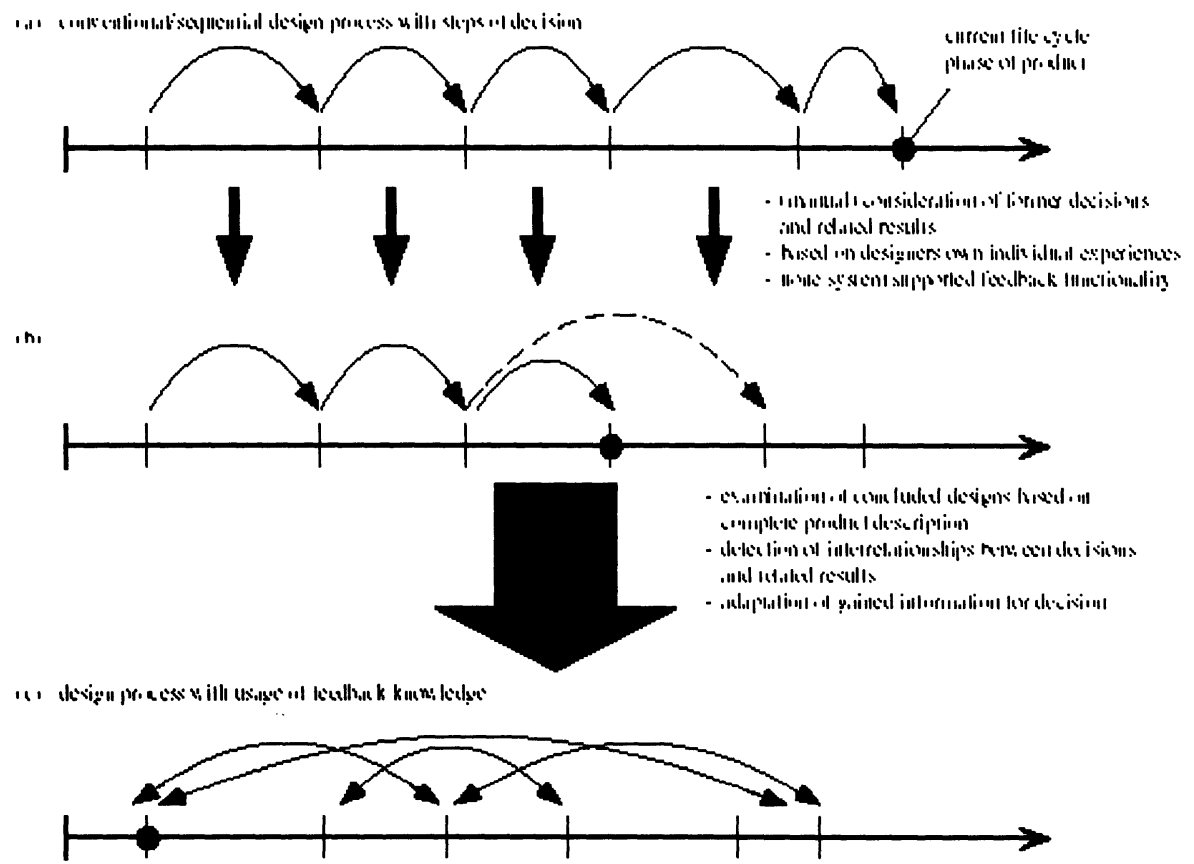

Figure 4 Knowledge feedback to design.

Having products with a more or less complete product description, the designer is able to extract such interrelationships manually and to use them when he is going to make improvements to his products or to create new products, i.e. using the experience and knowledge of already concluded designs. In this case he is able to profit from feedback in far earlier phases. Still, this is a manual process and that is the reason we call it quasi feedback. This means, that the designer could use descriptions of concluded designs but there is no intelligent retrieval to detect such interrelationships. Therefore the nearest goal is to build up such retrieval mechanisms. So the designer could search for situations similar to his current stage (e.g. products with comparable properties, information on a specific life cycle phase). He can look after related results, i.e. possible solution for his problem. That's why we call it feedback with manual adaptation. Moreover a next step may be to dedect possible interrelationships between decisions and related results by the system 
itself, i.e. a more sophisticated support to deduct support actions from arising design contexts. Relationships between experience and decisions taken before shall be extracted automatically such as it is done intutively by human beings. The designer there will have the opportunity to select either one or more of the proposed support actions to discover the most suitable one. It might also be that he will go another way in problem solving. As a consequence he must have the possibility to go (model interactively) such a new way (case). We call this feedback with automatic-interactive adaptation (figure $4 \mathrm{c}$ ). Still using this mechanism, but in a strictly automated form, may be another strategy. This means preventing the designer from making decisions. The most suitable solution/action will be detected and initiated by the system. Here we speak of feedback with automatic-autonomous adaptation. This may be a disputable strategy. It might however be useful, e.g. in a strongly bounded (high-complex) domain the designer has neither experiences nor reliable information. In our opinion this should be the exception. Having said that, we would like to stress the point, that automatic deduction shall not be used to take decisions but only to indicate possible interrelationships and solutions. This is to keep the power of deciding clearly in the hands of the designer. It can not be the goal to exclude him from any step of the design.

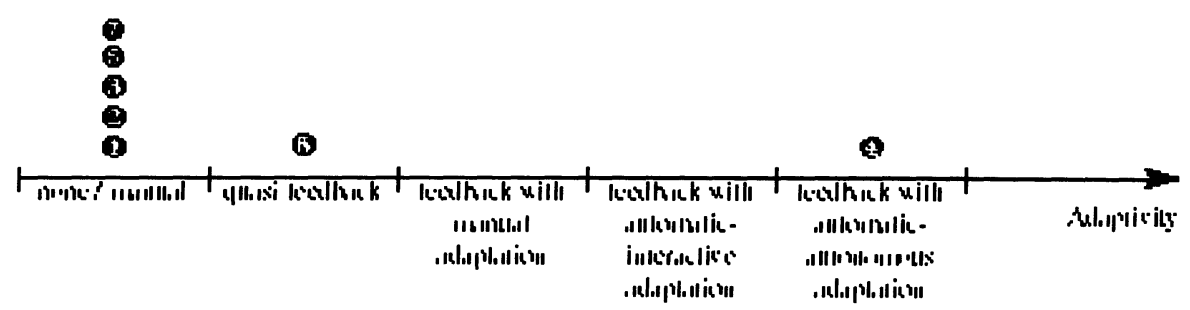

Figure 5 Kind of adaptation of knowledge - feedback strategies

Summarising the analysed projects from the viewpoint of feedback it is clear that most of them have only manual or quasi feedback. In practise this is to feed a data model with the more or less formalised experience and to make use of it during the design phases. However one system strive for more and we think that this will be the direction to go for in the future.

\section{CONCLUSION}

This paper is based on an internal investigation of performed projects at the IMW. All these projects are considered as relevant for design support strategies. The goal was to show an possible correlation between knowledge representation methods and advanced design support strategies. It states, that design support is mainly a feedback strategy of experience and knowledge from the past to the current state of the design or even for the use of approximations for the future. Different strategies 
have been identified. These vary in complexity and power of use, due to its underlying knowledge representation structure.

Some general remarks on building design support systems can be madeusing these rather theoretical results: Relieving a designer in the way of taking odd and ever repeating actions away from him means to model what in his mind is represented in an epistemic structure. This is to model certain data structures which will be matches with arising cases during the design and, in cases of fits, pre described actions could take place. This structure is rather static. (The odd thing about it is, that the modelled knowledge itself is originally a procedural knowledge which appears for modelling as a declarative and static one.) A more sophisticated support is to deduct support actions from arising design contexts or at least give the possibility to describe/model interactively such new cases. Here, a meta-model is needed and the system has to cope with the heuristic structure of the user. This view on knowledge representation, i.e. the view which takes care of the human memory structures, indicates the level of modelling and the complexity of application a system designer has to think about.

As already pointed out in previous chapters, several feedback strategies have been extracted. The simple use of documented data, the more advanced research in structured data and the extraction of relationships from the set of existing data and the set of (already) taken decisions. It is evident that future research has to concentrate on those systems which model information beyond simple data structures. Of interest are complex relationships which allow precise reductions of the solution space to be made (refer to (Fricke, 1996), tactics during the search for solutions balanced search).

The analysis seems to show a weighting towards of research for support systems concerning the embodiment and detailed design phase. This is also reflected in the overwhelming market for design tools which exactly concentrate on those phases (CAD systems and supplementing modules). On the other hand, two important gaps have shown up. One is the missing support of the planning and conceptual phase. The other is the missing extraction of information from the later phases. The sentence already implies the aim. We see the early phases still as a information target while the later phases are a source of them. In this paper we want to concentrate on the design (instead of the manufacturing, use and replacement) of a product. Further research should head into the direction of making use of as much information as possible to support decisions in the very early phases of a design. The information sources used for current support systems seems to be rather static and research concentrates on these. Actually, more unsettled data is more important, because this data is the critical type in terms of actuality, time, costs and so forth. This means, that future support systems should be nearer to such data and have to reflect changes of the data to the designer. He might be forced to revisit his decisions then. 


\section{REFERENCES}

AMANIS: AMANIS - Advanced Manufacturing Information System for the Designer. Cardiff: Brite-EuRam Project 5139, 1995 (Final Technical Report, AMANIS.CL.95.12)

Baya, V.; Leifer, L. J.: A Study of the Information Handling Behavior of Designers during Conceptual Design. T. K. Hight und F. Mistree (Hrsg.): DTM '94 International Conference on Design Theory and Methodology. (Tagung Minneapolis 1994) New York: American Society of Mechanical Engineers, 1994, p. 153-160 (, DE-Vol. 68)

DIN: DIN Fachbericht 69: Grundlagen für den Aufbau eines Merkmal-Lexikon. Berlin: NSM, DIN, (Fachbericht, NSM-0.3 Nr. 09-97)

DIN: Produktqualität durch Konstruktionsqualität - Modelle und Methoden für das Qualitätsmanagement in der Konstruktion. Berlin: Beuth Verlag, 1997

Dietz, P.; Penschke S.; Ort, A.: Strategies for Product Knowledge Management and feedback to Design - Application Examples. Workshop on Product Knowledge Sharing and Integration. (Tagung Sophia Antipolis 17.-18.4.1997) 1997

Dörner, D.: Problemlösen als Informationsverarbeitung. Stuttgart: Kohlhammer Verlag, 1979

EQUIP: EQUIP - Work Methodology for Development of Quiet Products. Delft: Brite-EuRam Project 5983, 28. Februar 1997 (Final Technical Report, EQ-PR$\mathrm{Vj})$

Fricke, G.: Successful Individual Approaches in Engineering Design. Research in Engineering Design Bd. 8 (1996) no. 3, p. 151-165

Görz, G. (ed.): Einführung in die künstliche Intelligenz. Bonn: Addison-Wesley Publishing, 1993

V. Hubka, Eder, W. E.: Design Science - Introduction to the Needs, Scope and Organization of Engineering Design Knowledge. Berlin: Springer Verlag, 1996

ISO/TC184/SC4: Parts Library - Part 42: Methodology for the Structuring of Parts Library Families. : ISO, 28.2.1996 (DIS, N 243)

Krause, F.-L.; Hayka, H.;Jansen, H.: Produktmodellierung als Basis für eine wettbewerbsfähige Produktentwicklung. J. Gausemeier (Hrsg.): CAD '94 Produktdatenmodellierung und Prozeßmodellierung als Grundlage neuer CAD-Systeme. (Tagung Paderborn 17./18. März 1994) München: Carl Hanser Verlag, 1994, S. 29-54

Lenau, T.; Alting, L.: Intelligent Support Systems for Product Design. Annals of the CIRP Bd. 38 (1989) no. 1, p. 153-156

Nilsson, N. J.: Principles of Artificial Intelligence. Berlin: Springer Verlag, 1982 
Ort, A.: ProManual: Erstellung elektronisch verfügbarer Produkthandbücher. P. Dietz (Hrsg.): Mitteilungen des Institutes für Maschinenwesen. 1. ClausthalZellerfeld: IMW, 1997, S. 51-54 (, 22)

Pahl, G; Beitz, W.: Konstruktionslehre: Methoden und Anwendung. Berlin: Springer-Verlag, 1993

Pham, D. T. (ed.): Artificial Intelligence in Design. A. Kusiak (Hrsg.), Berlin: Springer Verlag, 1991 (Artificial Intelligence in Industry)

PICASSO: PICASSO - Practical and Intelligent CAD for Assembly Objects. Birmingham: Brite-EuRam Project 5693, November 1996 (Final Technical Report)

Sardet, E.; Pierra, G.; Ait-Ameur, Y.: Formal Specification, Modelling and Exchange of Classes of Components according to PLib. A case study. (Tagung Antwerpen 1997

Weber, C.: What is a Feature and what is its use? - Results of FEMEX Working Group I. ISATA '96 29thInternational Symposium on Automotive Technology and Automotion. (Tagung Florence 3.-6. Juni 1996) 1996, p. 109-116

Yoshikawa, H.: Systematization of Design Knowledge. Annals of the CIRP Bd. 42 (1993) no. 1, p. 131-135

\section{BIOGRAPHY}

Prof. Dr.-Ing. P. Dietz, born 1939, studied machanical engineering in Darmstadt, doctorate 1971 on drum winches, since 1974 working for Pittler Maschinenfabrik, since 1980 head of the institute for mechanical engineering (IMW), TU Clausthal.

A. Ort, born 1968, studied computer science in Karlsruhe, since 1993 research assistant at the IMW, TU Clausthal, finished his doctorate April 1998.

S. Penschke, born 1965, studied mechanical engineering in Dresden, since 1993 research assistant at the IMW, finished his doctorate in March 1998, since May 1998 working for a consultant agency in Munich. 